\title{
顎咬合異常における咬合の再構成
}

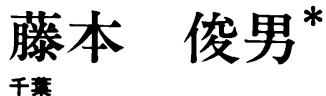

\section{A Casepresentation of Occlusal Reconstruction in Malocclusion}

Toshio Fujimoto, D.D.S., D.D.Sc.

Chiba

In prosthodontics, we have little chance of finding good ideal occlusions ( non-axiversion, non-transversion and non-torsiversion ). We often find malpositions of teeth, abnormalities of arch forms and abnormalities of arch relationships. In this case, we should correct malocclusion by surgical or orthodontic treatment before prosthodontic treatment. If we'11 correct malpositions of teeth and abnormalities of arch forms, we' 11 be able to establish more elastic, more functional and periodontal ideal occlusion.

So, we should have synthetic informations ( surgery, orthodontics, endodontics, periodontics and prosthodontics ) to occlusal diagnosis.

Now, I present a case of occlusal reconstruction, applying surgical treatment, minor tooth movement and surgical implantation of Bioceram type 5 SIS.

はじめに

補緅物を製作する場合，現存する歯が理想的な咬合 を営み、ただ単に歯冠補緅あるいは欠損補緅をすれば よいということは非常にまれであり，歯列に傾斜，転 位などの不正があり，全体の咬合も不正になっている ことが多い．また顎位に異常が存在することもある. このような場合, 補経処置を行う以前に, 外科および 矯正治療により不正を改善しておく必要がある。それ によって補緅作業を容易にするばかりでなく，番美的，

*千葉市にて開業

1982 年 7 月 15 日受付
機能的, 㐘周病学的にもよい咬合を確立することがで きる。

顎および咬合の異常を治療するには外科，矯正，歯 周，歯内および補綴の各分野から検討し綕合的に診断 し对処しなければならない。

今回, 顎の偏位を伴った咬合異常者の補緅を行うに あたり, 顎位の改善, 確立を重点におき十ソロジカル な咬合1の再構成を行うことにより審美的回復, 咀看 機能の回復, さらに発音機能の回復をはかり一応の成 果をおさめたので報告する。 


\section{症例}

患者：Y.W. 21 歳，女性。

主訴：上顎前歯部の審美的障害.

現症：全身的には特記すべき事項なし。

顔貌は下顎の右側偏位と前突感があり Skeletal analysis ${ }^{7)}$ において上顎の劣成長が認められる。咬 合状態では class 3 で下顎が正中より右側に約 5 $\mathrm{mm}$ 偏位しており，臼歯部において咬合面形態が失 われ（ $\frac{76556}{6555}$ 抜歯済み）, Vertical dimentionの 低下が認められる。咬頭嵌合位における臼歯部の 咬合接触は $\frac{4}{4} / 7$ のみである。なお年は近心傾斜

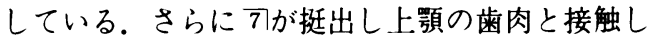
咬頭の圧痕が認められ，左側上䫛結節が異常に増 大し $\overline{7}$ と咬合接触している。前㐘部において， $\frac{3+3}{3+3}$ が反対咬合で, 正中線は約 $5 \mathrm{~mm}$ 右側に偏位 し，上の捻転が著しく正中に空隚が存在する.

中心位において， $\frac{3}{3}$ に早期接触が認められ 3金属冠尖頭部に咬頭干涉が存在する。また，構 成咬合 》はわずかしかとりえない。

既応歴： 歯科治療に恐怖感があり，12 年前に(32(1)

Bridge を調製して以来，歯科治療の経験はない。 そのため，来院時において，ほとんどの臼歯は崩 壊していた。

\section{診断および処置方針}

本症例は，歯科治療への極端な恐怖感から口腔状態 の破壊にもかかわらず，長期間放置していたため，顎 の偏位（顔貌の変化）および咬合異常をきたしたもの と思われる。

本症例において，補緅的再構成すべき点は，1，前 歯部の審美的回復（前歯部の反対咬合，し1の捻転 の治療)

2.顎位の改善による顔貌の回復

3. 臼歯部咬合面形態の回復および欠損部 $\left(\frac{76556}{65}\right)$ 補緅による咀㗍機能の回復

である。

前雬部の審美的回復および顎位の改善による顔貌の 回復にあたっては，外科的療法を行なった方が良いと 思われるが, 前述のごとく, 極度の恐怖心をもち 21 歳 という年項の女性であり,さらに本人の強い希望も あったため矯正専門医と相談した結果，できるだけ外
科的侵襲をさけ矯正および補緅処置により対処するこ ととした。臼歯部咬合面形態の回復にあたっては，咬 合異常をきたす因子を除去し，さらに顎位の改善につ とめ, スムースな下顎運動を行えるよう誘導し，中心 位において咬合構成を行うこととした。また欠損部補緅 においては，できるだけ固定性補緅物になるよう下䝷 において 6 相当にバイオセラムインプランドをを行 ない, (5)5(4)の fixed bridge を調製することとし、一 方，上顎の欠損補緅においては欠損歯数が多く，また， 歯槽骨の状態，上顎洞との位置関係からインプラント は不適当と判断し， removable denture を調製するこ ととした。

なおバイオセラムインプラント6に関し，さまざま な意見があり，いまだ十分解明していないが，適応症 例を選択し適当な咬合4を付与すれば，よい結果をも たらすと思われる。今回は，バイオセラムインプラン ト 5 SIS type を用い,トランスコルチカルインプラン トの考えにて行った。

\section{処置および経過}

1. 顎位の偏位をもたらした咬合障害物を除去し，歯内 療法および雬周処置を施した。

(1)不適合な (3)2(1) SP bridge を除去し $\frac{4 / 7}{4}$ の咬合 調整を行い咬合の安定をはかった。

(2) 77を抜去し，異常增殖した左側上頻結節周囲の歯槽 骨を除去し整形した。

(3)暫間補緅物の咬合平面を HIP plane ${ }^{3)}$ に合わせ調製 した。この結果，額位は正中において約 $3 \mathrm{~mm} の$ 偏位に 回復した。

2. 逐の捻転をM. T. M. により改善した。

321123 : edgewise bracket を装着し, 0.16 nitinol-

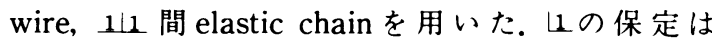
32112 の temporary crownにて行った。

3. 65 相当部にバイオセラムインプラント（5 SIS type)を行い，(55(4)の fixed temporary bridge を仮 着し，インプラントを固定した。

4.ここで, 頶位を改善すると同時に下顎運動をスム一 スにする目的でスプリントとしてチューイン法4,8)を 行った. 12 年間の習慣性颚位を正常な額位に回復する ことは困難であると思われるが，そのため，クラッチ に強制的なガイドを付与し，中心位に誘導し観察した。 


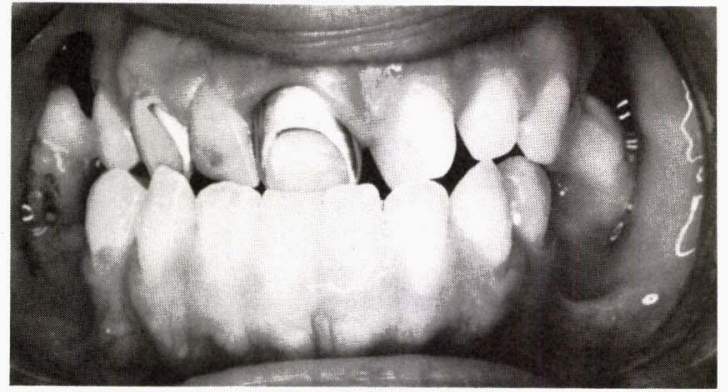

Fig. 1 初診時の口腔内所見, 唇側面観. class 3 で, 下顎が右 側に約 $5 \mathrm{~mm}$ 偏位している.

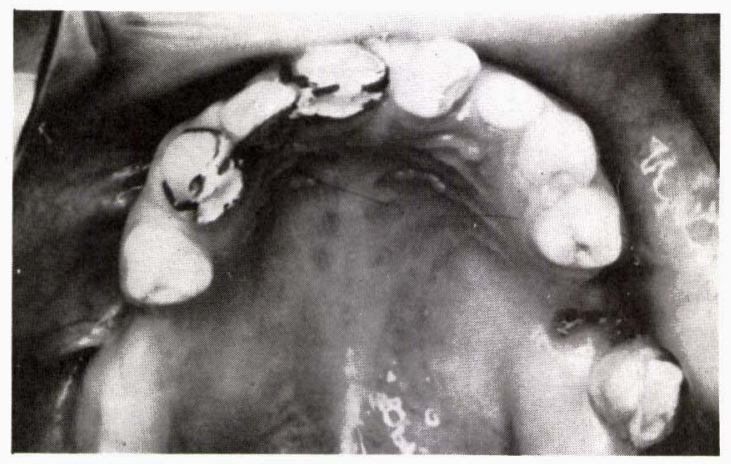

Fig. 3 上顎咬合面観. 这が約 $45^{\circ}$ 近心に捻転している. 左上顎結 節周囲に骨隆起が存在する。( 765156 抜歯済み)

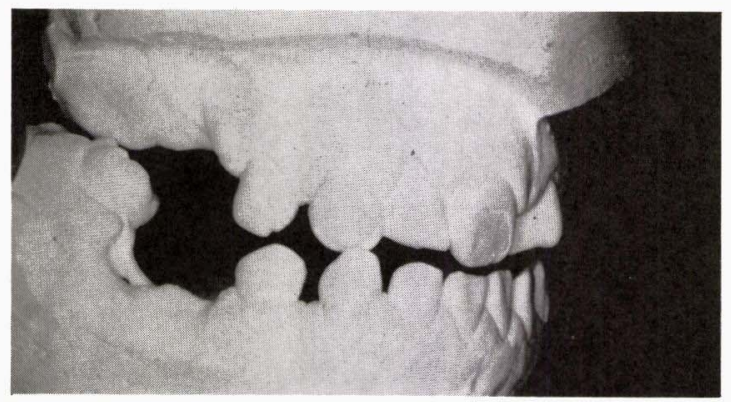

Fig. 5 スタディモデルによる咬合診查. 中心位における咬合状 態. 7 が異常挺出し, 対合する歯肉と接触している. また, $\frac{3}{3}$ に 早期接触を認める。

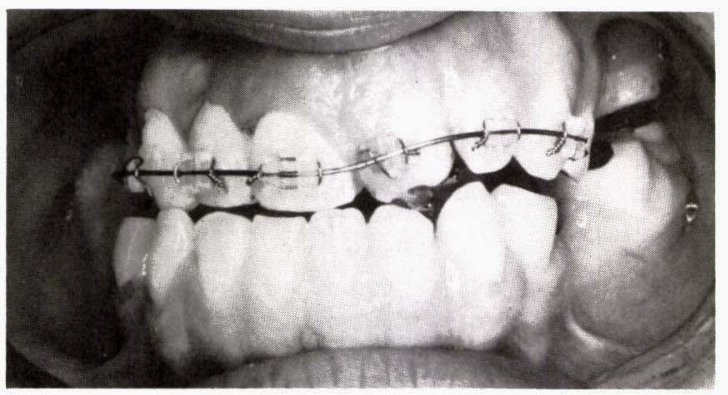

Fig.7 Edgewise bracket および0.16 nitinol wireによる M. T. M. の実旋.

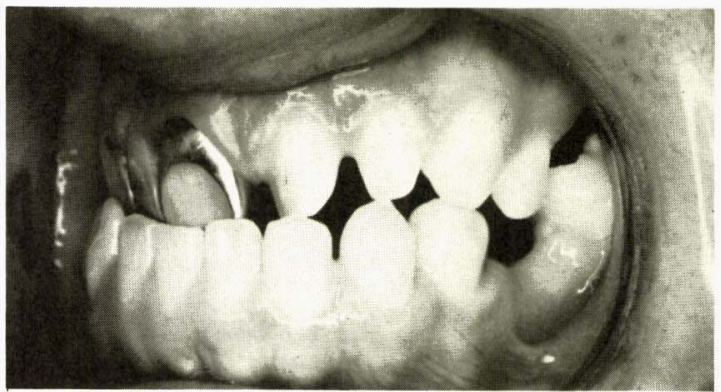

Fig. 2 術前側方面観.

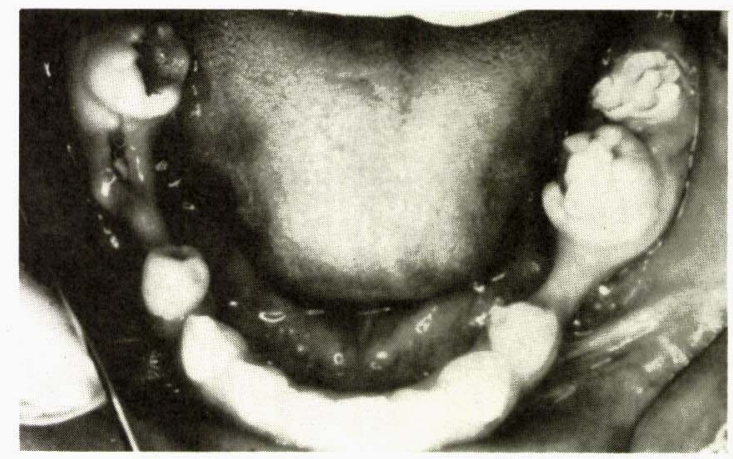

Fig. 4 下顎咬合面観.（ $\overline{6515}$ 抜歯済み）

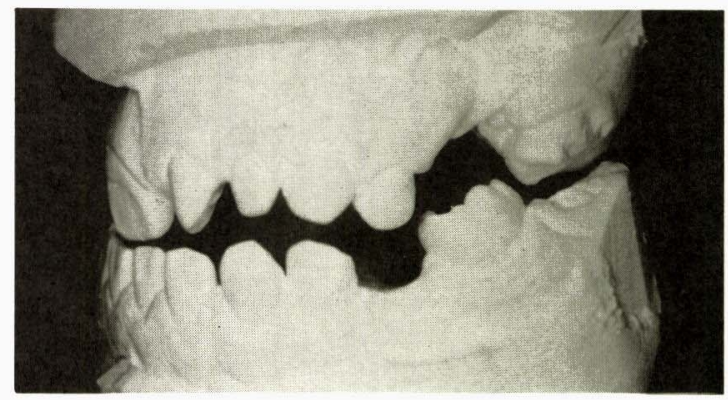

Fig. 6 咬合平面が乱れ, アンバランスな状態を示している.
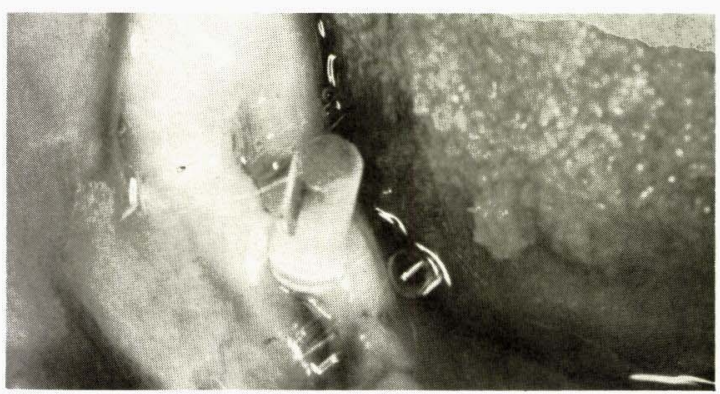

Fig. 8 インプラントを完了した状態.（5 SIS type） 


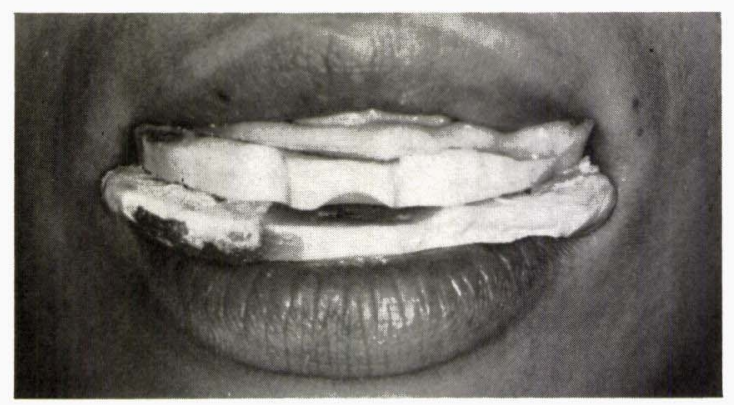

Fig. 9 チューインにより下顎を左側へ誘導し，スムースな下顎 運動を行わせる。

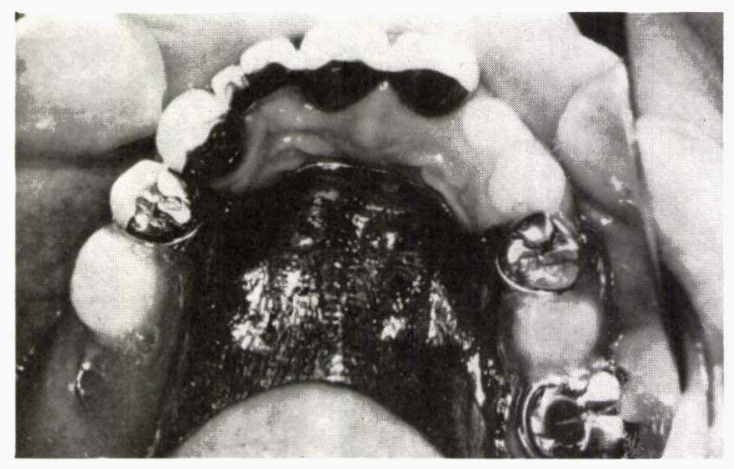

Fig.11 術後の口腔内所見

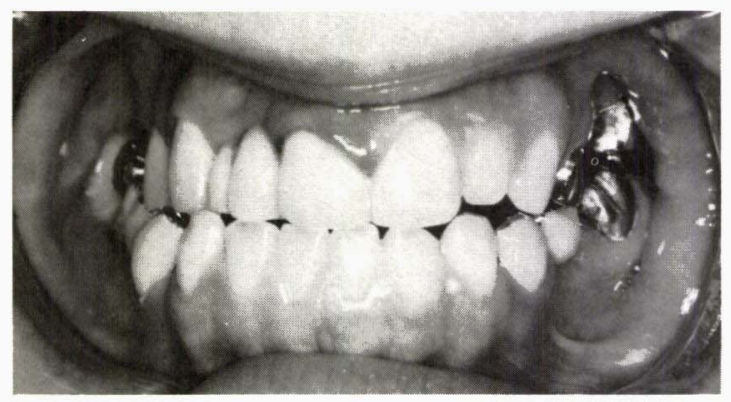

Fig.13

その結果, 約 1 力月後において約 $1 \mathrm{~mm}$ 右側への偏位 に回復し安定した。なお，クラッチのトレース部分に はTM Jレジンでは柔らかいため, 即時重合レジンを 用い調整を繰り返し行った。

5。パントグラフトレーシングにて下顎運動を記録し た結果, スムースな下顎運動が記録された。しかし class 3 のため, 前方運動距離は少なかった。

6 . 通法に従い, 支台形成および印象採得を行い最終 補緅物を調製した。

補緅物の調製にあたっては, 咬合様式は disclusion ${ }^{4}$

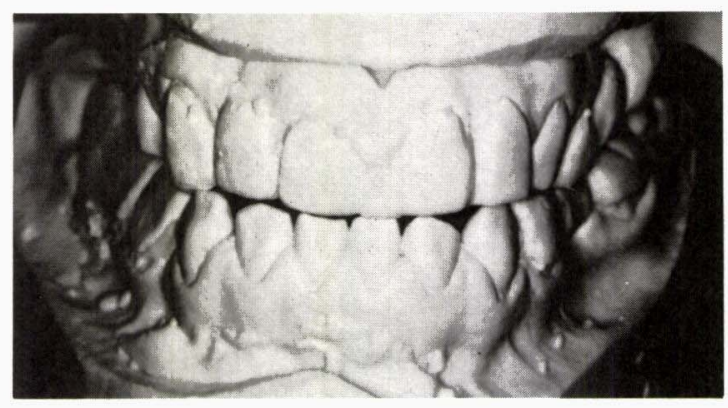

Fig.10 咬合平面をHIP planeにあわせ調製した temporary crownの対交関係.

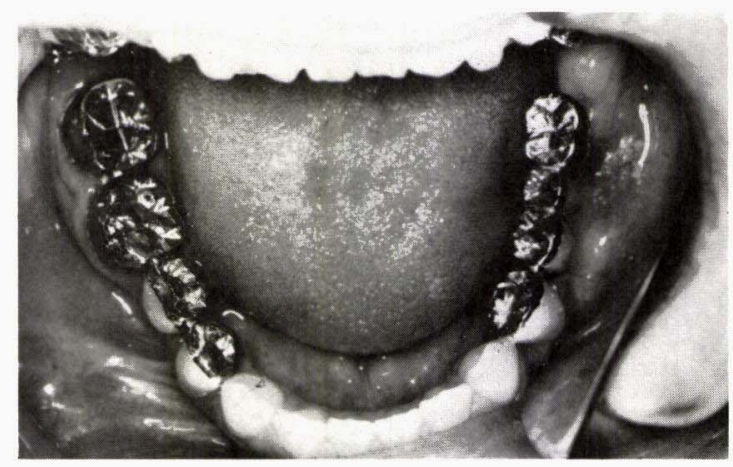

Fig.12

としたが，顎位の relapse 防止のため， cuspid rise を

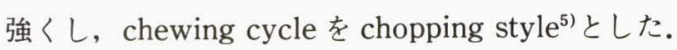

\section{考察}

本症例のように，顎位を外科的な観血処置により回 復できない場合，初診時の顎位で補経するのではなく，

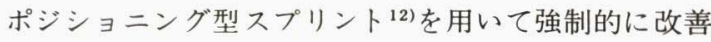
するのも一方法として考えられる。しかし，この方法 は困難が多く,また改善されたとしても, relapseの問 題がある。本症例一例だけで論議, 判定するわけには いかないが，最近多くみられる顎関節症患者における 咬合異常 ${ }^{12)}$ の治療と併せて検討していかなければなら ない，また，適応症すなわち，顎関節の状態，顎位の 偏位の程度，咬合状態を十分考慮しなければならない。

一方, Roth ${ }^{13)}$ は満足な矯正治療ができたとしても, 満足な機能的結果を得ることの難しい不正咬合の夕イ プとして, 顔面の非対称性を有する症例, およびほ，と んどのIII級症例などをあげている。そして,これらの 症例においては, terminal hinge position でI 級の臼 歯関係に嵌合させることや,十分なanterior guidance 
を得ることが難しいと指摘している. 本症例において も，中心位において，I 級の田歯関係に嵌合させるこ とは困難であり，、anterior guidanceも十分得られな かった。

また，もう1つの問題として，矯正および外科治療 後に補緅処置を行うにあたり重要なことは, 改善, 修 正された状態をいかに維持するかということ，すなわ ち，欠損補緅による機能および審美性の回復，修正の ほかに，外科あるいは矯正治療により得られた顎位， 歯牙位および咬合の安定（歯列弓およU゙歯牙の relapseの阻止)を目的とした補緅でなければならない.大 山商10) は唇顎口蓋裂患者の補経において, 歯槽弓および 歯牙の relapse を阻止する設計が必要であるとし，い くつかの報告をしている。

通常,一般的な個体では外傷性咬合がなければ通常 の咬合力の垂直的ならびに水平的分力に十分对応でき る生理学的機構を歯周組織が有していると考えられる が，矯正および外科治療を行った個体の歯周組織は，

健常人と比較し, 生理学的安定性が低下していると思 われる。さらに，適切な咬頭嵌合位を与之通常の咬合 力であっても，持続的に与えられる小さな矯正力に对 し，断続的だが繰り返し加わる大きな咬合力のさま ざまな方向への分力が歯牙の relapseを誘発し,さら には, 額位の relapseを毛助長しやすい. まして, 本症 例においてはインプラントを行っているため, インプ ラントへの負担も考慮しなければならない。

そこで, 補緅治療上において, 以下の点に注意して 設計した。

（1〕咬合力を分散する設計として1）臼菊部にお いて，しっかりとした咬頭嵌合位を中心位 ${ }^{2}$ で確立し た２）咬合状態は, 上顎が局部床義歯のためリンガラ イズド・オクルージョンとし，咬頭嵌合位で上類臼歯 舌側咬頭のみを, 下額臼歯咬合面に接触させ, さらに, 下額臼歯は flat な咬合面形態とした３）側方運動時

\section{参考文献}

1) 保母須弥也編：咬合学辞典. 書林, 東京, 1978

2) 村岡 博：セントリック・ロケーター（中心位の再現と採得 を容易にする器具).デンタルタイジェスト,クインテッセン
の咬合様式4)は disclusion とし, cuspid riseを強くし て chewing cycle をせばめ, chopping style ${ }^{5)}$ の咬合様 式としたこれにより, centric occlusionはしっかり固 定し, 咬合力は垂直的に加わり, 側方圧は少なく, 歯 牙およびインプラントへの負担も軽減すると思われ, さらに顎位の relapse 防止にも役立つと思われる。

〔2〕一方前歯部においては, 矯正した前歯部茵牙 の relapse 防止のため, 連続冠で固定した。さらに，III 級のため anterior guidance が十分得られないが, 頻 位の relapse防止のためできるだけ over biteを付与 するよう努めた。

〔3〕口腔衛生上, 不潔域を可及的に少なくする設 計として, 特に, 片側遊離端の下顥において, 延長ブ リッジあるいは可撤性義歯とせず，インプラントによ る固定性ブリッジ6)とした. 術後 1 年ではあるが, イン プラント周用の歯肉の状態は良好である。また動摇は 認められない。

本症例の予後観察をする目的で術前術後の中心咬合 位における咬合力を测定した。その結果，術前におい て左側 $8 \sim 12 \mathrm{~kg}$, 右側 $9 \sim 14 \mathrm{~kg}$ が術後 1 週間におい て左側 $27 \sim 30 \mathrm{~kg}$, 右側 $28 \sim 32 \mathrm{~kg}$, 術後 1 年におい て左側 $28 \sim 33 \mathrm{~kg}$, 右側 $30 \sim 34 \mathrm{~kg}$ と咬合力は増大した。 このことから，中心位において前述のような咬合再構 成を行うことにより咀嚼機能が回復され, 術後 1 年 において, 顎位および, 歯牙の relapse は存在せず,一 応の成果をおさめたと思われる. 今後さらに, 予後観 察を行い, 検討していく所存です.

\section{おわりに}

本症例は極端であると思われるが, 日常臨床におい て, 外科, 矯正, 歯内, 歯周および補緅の各分野から 総合的に検討し，より良い咬合を確立しなければなら ないことを示唆している。

最後に, つたない症例報告ではありますが, 先輩諸 兄の御意見，御批判を賜わりたいと存じます。

ス $3: 27 \sim 37,1980$

3 ）管野博康：フル, マウス, リコンストラクションの一症例. J. A. Gnath., 2(1) : 7 16, 1980

4 ) 藤本俊男ほか：バイ,ラテラル,バランスド,オクルージョンと 
ディスクルージョン.J. A. Gnath., 2 (1) : 57〜70, 1980

5 ) 藤本俊男：絵義歯における咬合型式の相違による咀程力およ び咀啨筋筋電困に関する研究. 補緅誌 $24: 9 \sim 29,1980$

6 ）川原春幸ほか：バイオセラムサファイアインプラントの手引

〈菌科編〉。ハイイオ七ラムオーラルインプラント研究会, (京 都), 1979

7 ) 榎 恵: 歯科矯正学, 医菌薬, (東京), 1975

8 ）大坪卓史：チューイン法による関節窩形態の変化に関する研 究一術者間および日間の差について一. 補緅誌 23 ： 216 238, 1979

9 ）大山喬史：唇額口蓋裂と困科補緅。日本雪科評論，400： $29 \sim 36, \quad 1976$
10）大山喬史：口蓋裂患者の欠損部補緅の基本的な考之．顔顔面 補緅， $2: 33 \sim 36 ， 1979$

11）筒井昌秀ほか：矯正治療後フルマウス補緅処置を行った 2 治 験例について。西稪会誌, $22: 102,1977$

12）石橋成六：臨床生理咬合と T M J 機能障害, 書林, (東京), 1979

13) Roth, R. H. : Gnathological concepts and orthodontic treatment goals-Technique and treatment with the ligth wire appliances. Mosby ( St. Louis ) , 1972

14) Gnathostomatic finishing systems. Oral art, Orthodontic laboratory Inc. (California )

15）小坂 : 矯正治療と Functional occlusion-Gnathological finishing について一. 日本歯科評論, $436: 137 \sim 143,1979$ 